\title{
Diagnostic and prognostic value of the peripheral natural killer cell levels in gastric cancer
}

\author{
YU-YAN CHEN $^{1,2^{*}}$, YING FENG $^{1 *}$, QIN-SHENG MAO $^{1}$, PENG MA $^{1}$, JIA-ZHOU LIU $^{1,2}$, \\ WEI LU ${ }^{3}$, YI-FEI LIU ${ }^{4}, \mathrm{XI} \mathrm{CHEN}^{1}$, YI-LIN HU ${ }^{1,2}$ and WAN-JIANG XUE ${ }^{1,2}$ \\ ${ }^{1}$ Department of Gastrointestinal Surgery, Affiliated Hospital of Nantong University; ${ }^{2}$ Research Center of Clinical Medicine, \\ Nantong University, Affiliated Hospital of Nantong University; Departments of ${ }^{3}$ Hematology and \\ ${ }^{4}$ Pathology, Affiliated Hospital of Nantong University, Nantong, Jiangsu 226001, P.R. China
}

Received January 30, 2020; Accepted June 24, 2020

DOI: $10.3892 / \mathrm{etm} .2020 .9101$

\begin{abstract}
Peripheral blood lymphocyte subsets have been reported to be useful as prognostic and/or diagnostic markers for patients with cancer. However, the clinical value of peripheral blood lymphocyte subsets in gastric cancer (GC) has remained elusive. In the present study, peripheral $\mathrm{CD}^{+}$, $\mathrm{CD}^{+}$and $\mathrm{CD}^{+} \mathrm{T}$ lymphocytes, $\mathrm{B}$ cells $\left(\mathrm{CD} 19^{+}\right)$, regulatory T cells (Tregs; $\mathrm{CD}^{+}{ }^{+} \mathrm{CD} 25^{+} \mathrm{CD} 127^{-}$) and natural killer $(\mathrm{NK})$ cells $\left(\mathrm{CD} 3{ }^{-} \mathrm{CD} 16^{+} \mathrm{CD} 56^{+}\right)$were detected by flow cytometry in 122 patients with GC, 80 healthy donors (HDs) and 80 patients with gastric ulcer $(\mathrm{GU})$. NK cells $\left(\mathrm{CD} 56^{+}\right)$were detected by immunohistochemical (IHC) analysis in $20 \mathrm{GC}$ and three GU tissue samples. A receiver-operating characteristic (ROC) curve was used to determine the threshold of the peripheral NK cell level and survival analysis was performed to assess its prognostic value in patients with GC. The results indicated that the peripheral NK cell proportion in patients with GC (18.77\%) was significantly higher than that in the HD (12.19\%) and GU (12.74\%) groups. IHC analysis suggested that the $\mathrm{NK}$ level in GC tumor samples was correlated with that in paired serum samples. ROC curve analysis indicated that the peripheral NK cell level $(15.16 \%)$ was able to effectively identify patients with GC, a diagnostic sensitivity of $75.41 \%$ and a specificity of $77.45 \%$ were determined. Multivariate logistic regression analysis revealed that the peripheral NK cell level was independently associated with the $\mathrm{T}$ stage and survival analysis demonstrated that high levels of peripheral NK cells
\end{abstract}

Correspondence to: Dr Wan-Jiang Xue or Dr Yi-Lin Hu, Department of Gastrointestinal Surgery, Affiliated Hospital of Nantong University, 20 Xisi Street, Nantong, Jiangsu 226001, P.R. China

E-mail: xuewanjiang@ntu.edu.cn

E-mail: hyl510@ntu.edu.cn

*Contributed equally

Key words: natural killer cell, gastric cancer, diagnosis, prognosis, peripheral lymphocyte subsets were associated with poor prognosis of patients with GC. In conclusion, the peripheral NK cell level may be a diagnostic and prognostic marker for patients with GC.

\section{Introduction}

Gastric cancer (GC) is the fourth leading cause of cancer-associated mortality among the most common malignancies, with nearly 760,000 deaths resulting from GC each year $(1,2)$. GC has no specific manifestation at the early stage and $>80 \%$ of patients with GC present with advanced or late-stage GC upon diagnosis (3). Thus, early diagnosis of GC is particularly important and more effective non-invasive diagnostic markers for early GC are urgently required.

Peripheral lymphocyte subsets are important cells in the immune system $(4,5)$. Peripheral blood lymphocyte subsets mainly include T lymphocytes, B lymphocytes (CD19+) and natural killer $(\mathrm{NK})$ cells $\left(\mathrm{CD} 3{ }^{-} \mathrm{CDl}^{+} \mathrm{CD} 56^{+}\right)$. According to the presence of different cell surface markers, $\mathrm{T}$ lymphocytes may be divided into various phenotypic and functional groups, including $\mathrm{CD}^{+}, \mathrm{CD}^{+}$and $\mathrm{CD} 8^{+} \mathrm{T}$ cells, and regulatory $\mathrm{T}$ cells (Tregs; $\mathrm{CD}^{+} \mathrm{CD} 25^{+} \mathrm{CD} 127^{-}$). T cells and NK cells are mainly involved in cellular immunity, while B cells are involved in humoral immunity (5-8).

Changes in the peripheral lymphocyte subsets of tumor patients not only reflect the state of immune functions but are also closely linked to the clinical phenotype of tumors (9). Low levels of $\mathrm{CD}^{+} \mathrm{T}$ cells in peripheral blood are associated with the poor prognosis of patients with colon, endometrial or lung cancer (10-12), while low levels of $\mathrm{CD}^{+}$and $\mathrm{CD}^{+} \mathrm{T}$ cells are associated with the poor prognosis of patients with breast (13), colorectal (14) and cervical cancer (15). Certain studies have indicated that the proportion of $\mathrm{CD}^{+}$and $\mathrm{CD}^{+} \mathrm{T}$ cells tends to be stable, fluctuating between 1.3 and $2.0 \%$ in healthy individuals and may also be a good prognostic marker for lung and cervical cancer $(16,17)$. CD19 is able to specifically reflect changes in B lymphocytes and $\mathrm{CD} 19^{+} \mathrm{B}$ cells were proven to be a prognostic marker for nasopharyngeal carcinoma (18). Tregs are a group of lymphocytes that negatively regulate the immune response and have an important role in maintaining self-tolerance and avoiding excessive immune damage to the body. Studies have suggested that high levels of Tregs lead 
to poor prognosis in patients with colorectal or esophageal cancer $(19,20)$. NK cells are a group of lymphocytes with innate immune function. Low levels of NK cells have been indicated to be associated with a favorable prognosis in patients with esophageal or pancreatic cancer $(21,22)$. In spite of the increase of clinical research on lymphocyte subsets in peripheral blood, only a few systematic studies have reported on the distribution of lymphocyte subsets in the peripheral blood of patients with GC (23).

In the present study, the distribution of peripheral lymphocyte subsets in healthy donors (HDs), patients with gastric ulcer (GU) and patients with GC was explored and the value of NK cells as a diagnostic and prognostic marker for GC was revealed.

\section{Materials and methods}

Patients. To determine the minimum sample size in the HD, GU and GC groups for inclusion in the present study, the following formula was used to calculate the sample capacity: $\mathrm{n}_{1}=\mathrm{Z}_{\alpha}{ }^{2} \operatorname{Sen}(1-\operatorname{Sen}) / \Delta^{2}, \mathrm{n}_{2}=\mathrm{Z}_{\beta}{ }^{2} \operatorname{Spe}(1-\mathrm{Spe}) / \Delta^{2}$, where $\mathrm{n}_{1}$ is the case sample capacity, $\mathrm{n}_{2}$ the control sample capacity, Sen is the sensitivity, Spe is the specificity, $Z_{\alpha}=Z_{\beta}=95 \% \mathrm{CI}=1.96$ and $\Delta=0.1$. The minimum sample capacity was determined to be 72 for GC and 68 for GU and HD. Peripheral blood samples were collected from 122 patients with GC prior to radical D2 surgery for $\mathrm{GC}$ at the Affiliated Hospital of Nantong University (Nantong, China) from January 2013 to December 2013. Informed consent was obtained from all included participants. A total of 122 patients with primary GC scheduled for radical D2 surgery for GC were selected according to the following criteria: i) Patients were not older than 80 years; ii) patients did not receive any chemotherapy drugs prior to or after surgery; iii) patients had no known infectious diseases within 1 month prior to surgery; iv) patients had no obvious symptoms of fever; v) no blood transfusion was performed during surgery and within 1 month after surgery or 3 months prior to surgery; vi no infection or other complications occurred after surgery; and vii) tumors were TNM stage I, II or III. A uniform follow-up procedure was performed based on the clinical guidelines of the Japanese GC Association Classification of Gastric Carcinoma, 13th edition (24). The present study was approved by the Ethics Committee of the Affiliated Hospital of Nantong University (Nantong, China) in accordance with the tenets of the Declaration of Helsinki.

Blood sample collection and flow cytometry. Fasting venous blood samples were collected in heparin anticoagulant tubes and the samples were incubated with four-color monoclonal antibodies at room temperature for 15 min as follows: A CD3-FITC/CD8-PE/CD45-peridinin chlorophyll (PerCP)/CD4-allophycocyanin (APC) four-color kit (Mindray Medical International Co., Ltd.; cat. no. 340443; 1:1) and a CD3-FITC/CD16+56-phycoerythrin (PE)/CD45-PerCP/CD19-APC four-color kit (Mindray Medical International Co.,Ltd.; cat.no. 652834,1:1) were used to identify $\mathrm{CD}^{+}, \mathrm{CD}^{+}, \mathrm{CD}^{+}$and $\mathrm{CD} 19^{+} \mathrm{T}$ cells and $\mathrm{NK}$ cells, respectively, while a CD45-PerCP/CD4-APC/CD25-PE/CD127-FITC four-color kit (BD Biosciences; cat. no. 6029623, 1:1) was used to identify Tregs. After $15 \mathrm{~min}$, flow cytolytic lysing agent
(Mindray Medical International Co., Ltd.; cat. no. 2018110601) was added. The aforementioned kits were used according the manufacturers' protocols and all of the prepared samples were assayed using a BriCyte E6 flow cytometer (Mindray) and a minimum of $3 \times 10^{3}$ cells were recorded. A particular uniform protocol was followed that was published previously (9).

Immunohistochemical (IHC) analysis. In brief, GC or GU tissues were paraffin-embedded and cut into sections $(4 \mu \mathrm{m}$ thick). The sections were dewaxed in xylene and then rehydrated using a graded ethanol series. After three washes with PBS, the sections were incubated overnight at $4^{\circ} \mathrm{C}$ with the anti-CD56 antibody (Fuzhou Maixin Biotech Co., Ltd.; cat. no. Kit-0028, 1:100), an NK cell marker. After three washes with PBS, the sections were incubated with a horseradish peroxidase-conjugated secondary antibody (Dako, Agilent Technologies, Inc.; cat. no. S0809; 1:150) for $2 \mathrm{~h}$ at room temperature. Finally, hematoxylin and xylene were used to counterstain the sections. The staining intensity was scored manually in the microscope by two independent experienced pathologists. Brown-stained lymphocytes were defined as positively stained cells. The final IHC score was calculated using the average proportion of positively stained cells among lymphocyte cells in five random fields.

Statistical analysis. Statistical analysis was performed using SPSS version 17.0 statistical software (SPSS Inc.). The results are expressed as mean \pm standard deviation (SD). One-way analysis of variance followed by the Student-Neumann-Keuls post hoc test was used for comparison among the GC, GU and HD groups. The Student's t-test was used for comparing the NK cell ratio between cancer associated death and those who were still alive after 5 years. The correlation of NK cell levels between serum and paired tumor tissue samples was analyzed by Spearman correlation analysis. The sensitivity and specificity to identify GC and HD based on the peripheral NK cell level were analyzed and the best cutoff was determined by receiver-operating characteristic (ROC) curve analysis. The $\chi^{2}$ test was used to determine the association between the level of peripheral NK cells and clinicopathological features. Clinical and pathological data at the time of resection were analyzed to identify factors that influenced the prognosis via the Cox proportional hazards model. Multivariate analysis was performed by the Cox proportional hazards regression model. Kaplan-Meier analysis with a log-rank test was performed to determine the overall survival (OS) of patients with GC based on the level of peripheral NK cells. $\mathrm{P}<0.05$ was considered to indicate statistical significance.

\section{Results}

Distribution of lymphocyte subsets in patients with gastric diseases. Flow cytometry was used to detect the distribution of peripheral blood lymphocyte subsets in 80 HDs (age, $59.77 \pm 12.06$ years; 50 male, 30 female), 80 cases of GU (age, $60.26 \pm 11.23$ years; 42 male, 38 female) and 122 cases of GC (age, 56.41 \pm 11.92 years; 37 male, 85 female) (Fig. 1). $\mathrm{CD}^{+}$, $\mathrm{CD}^{+}$and $\mathrm{CD}^{+} \mathrm{T}$ cells, as well as $\mathrm{CD} 19^{+} \mathrm{B}$ cells, were lower in patients with GC than in HDs and GU cases but with no 

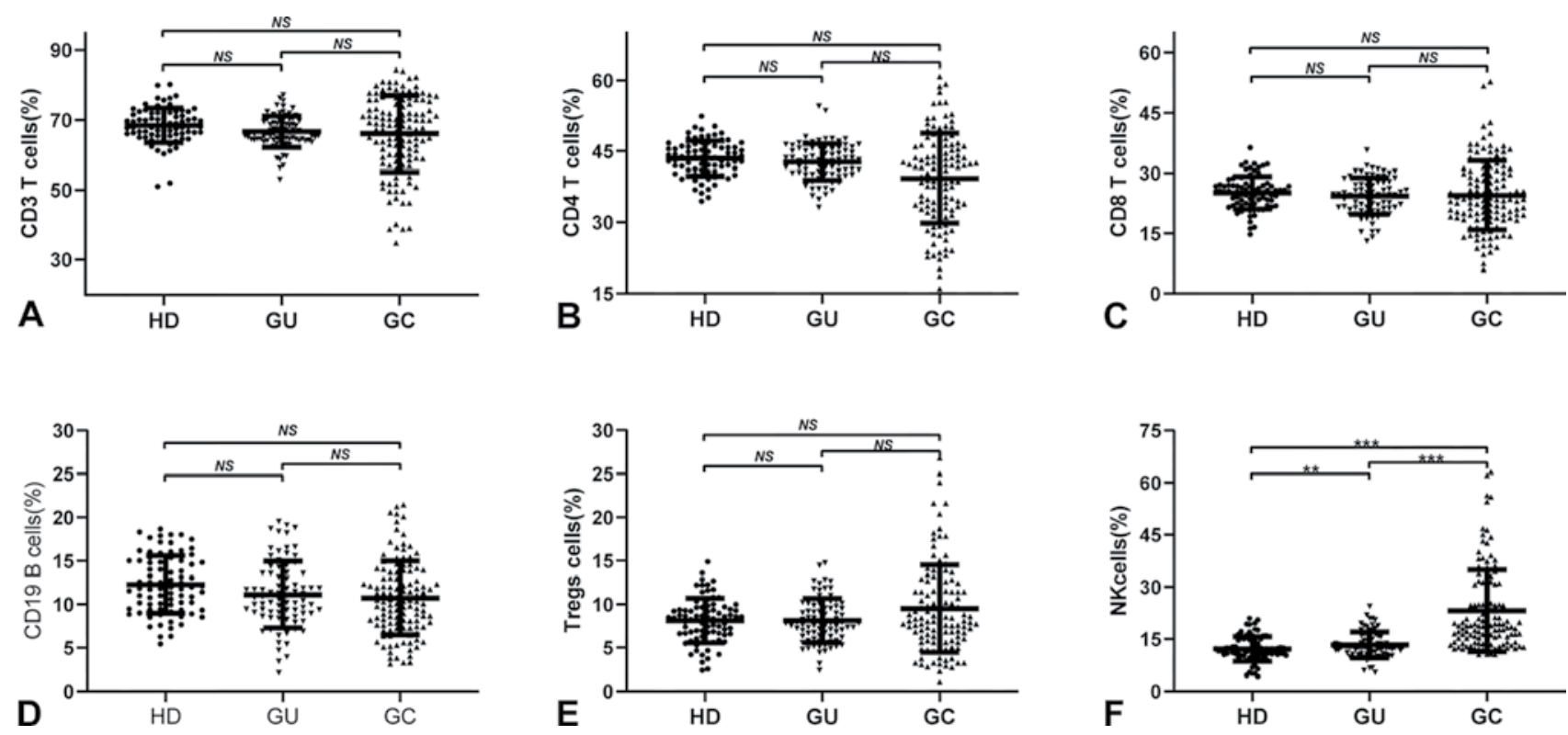

Figure 1. Distribution of peripheral lymphocyte subsets in different gastric diseases. Distribution of peripheral (A) $\mathrm{CD}^{+} \mathrm{T}_{\text {cells, }}(\mathrm{B}) \mathrm{CD}^{+} \mathrm{T}_{\text {cells, }}(\mathrm{C}) \mathrm{CD}^{+}$ T cells, (D) CD19+ $\mathrm{T}$ cells, (E) Tregs cells and (F) NK cells in HDs, GU cases and GC cases, respectively. One-way analysis of variance was used for comparisons between groups. ${ }^{* *} \mathrm{P}<0.01,{ }^{* * *} \mathrm{P}<0.001$. NS, no significance $(\mathrm{P}>0.05)$; HD, healthy donor; GU, gastric ulcer; GC, gastric cancer; Treg, T-regulatory; NK, natural killer.

statistical significance ( $\mathrm{P}>0.05$; Fig. 1A-D). Tregs levels were higher in patients with GC than in HDs or cases of GU, but there was no significant difference $(\mathrm{P}>0.05$; Fig. 1E). Of note, the level of NK cells in patients with GC was significantly higher than that in HDs $(\mathrm{P}<0.001 ; 95 \% \mathrm{CI}=7.51-12.51)$ and patients with $\mathrm{GU}(\mathrm{P}<0.001 ; 95 \% \mathrm{CI}=8.31-13.67$; Fig. 1E).

NK cell levels are correlated between paired serum and tumor samples from patients with GC. Next, IHC analysis of NK cells (CD56) was performed in samples from patients with $\mathrm{GC}(\mathrm{n}=20)$ and ulcer tissue samples from patients with $\mathrm{GU}(\mathrm{n}=3)$, revealing that the NK cell level in GC tissues was notably higher compared with in GU tissues (Fig. 2A). Further comparison revealed a strong positive correlation between the NK cell levels of paired tumor serum and tissue samples from patients with GC (Spearman R=0.898; P<0.001, Fig. 2B).

Peripheral NK cell levels are able to effectively distinguish patients with GC from HDs. The median proportion of NK cells among lymphocytes in patients with GC $(\mathrm{n}=122)$ was $18.77 \%$ and the interquartile range (IQR) was $13.54-31.18 \%$. However, in HDs $(n=80)$ and patients with GU $(n=80)$, the median proportion of NK cells was $12.19 \%$ (IQR, $10.32-14.77 \%$ ) and $12.74 \%$ (IQR, 11.42-16.01\%), respectively. In addition, the one-way analysis of variance revealed that the level of peripheral NK cells was increased in the GU group as compared with that in the HD group, and in the GC group as compared with that in the GU group $(\mathrm{P}=0.026$ and $\mathrm{P}<0.001$, respectively), indicating that the level of NK cells increased with the progression of the disease. An ROC curve was generated and demonstrated that the peripheral NK cell levels were able to effectively identify patients with GC and HD (Fig. 3). The area under the curve was 0.846 (95\% CI: 0.789-0.893; $\mathrm{P}<0.001$ ), while the best cut-off diagnostic threshold of NK cells for GC was $15.16 \%$. For this critical value, a diagnostic sensitivity of $75.41 \%$ and a specificity of $77.45 \%$ were determined. The false-positive rate was $24.59 \%$ and the false-negative rate was $22.55 \%$. At the critical value of $15.16 \%$, the proportion of patients with high levels of NK cells in the GC, HD and GU groups were $75.41 \%$ (92/122), $22.55 \%$ $(18 / 80)$ and $26.25 \%(21 / 80)$, respectively.

Peripheral NK cell levels in patients with GC are associated with clinicopathological features. To determine the clinical importance of peripheral NK cell levels in patients with GC, the association of the peripheral levels of NK cells with various clinicopathological features in 122 patients with GC was determined. High NK cell levels were defined as $>15.16 \%$ and low NK cell levels as $\leq 15.16 \%$ based on the previously determined NK cell level cutoff in patients with GC. $\chi^{2}$ test indicated that high levels of peripheral NK cells were associated with the $\mathrm{N}$ stage, $\mathrm{T}$ stage and TNM stage (Table I). However, multivariate analysis suggested that high levels of peripheral NK cells were only independently associated with the $\mathrm{T}$ stage $[\mathrm{P}=0.031$; hazard ratio $(\mathrm{HR})=3.278$; 95\% CI: 1.113-9.656].

High levels of NK cells in patients with GC are linked to poor survival. Kaplan-Meier survival curves were drawn to determine the association of the levels of peripheral NK cells with OS. The results indicated that patients with high peripheral NK cell levels had a shorter OS than those with low levels of NK cells $(\mathrm{P}=0.004$; Fig. 4A). In addition, at the 5-year follow-up, 69 patients had died, while 53 patients remained alive, with a 5 -year mortality rate of $56.6 \%$. The median proportion of NK cells was significantly higher in patients who had deceased (20.77\%; IQR, 16.38-34.38\%) than in those who were still alive after 5 years (17.50\%; IQR, 12.80-20.82\%; P=0.002; Fig. 4B). Next, multivariate analysis suggested that the level of peripheral NK cells were independent predictors of OS in patients with GC ( $\mathrm{P}=0.018$; HR=2.637; 95\% CI: 1.305-5.328; Table II). 

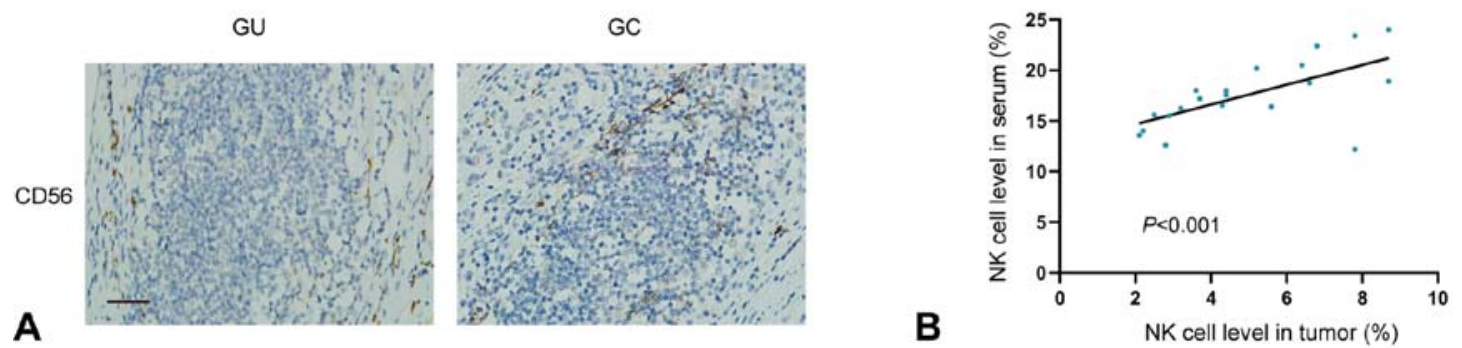

Figure 2. NK cell levels are correlated between paired serum and tumor samples from patients with GC. (A) Representative immunostaining images of NK cells (CD56) in $20 \mathrm{GC}$ and $3 \mathrm{GU}$ tissues. Blue stains the nucleus, while brown stains CD56 (scale bar, $100 \mu \mathrm{m}$ ). (B) A scatter plot illustrates the correlation of the NK cell levels between paired serum and tumor tissues from patients with GC (Spearman's $\mathrm{R}=0.898 ; \mathrm{P}<0.001$ ). GU, gastric ulcer; GC, gastric cancer; NK, natural killer.

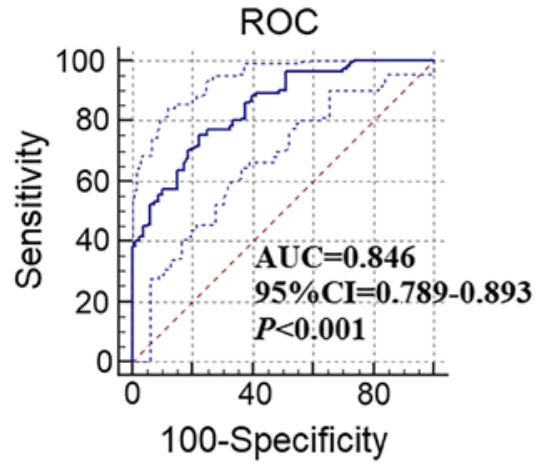

Figure 3. ROC curve illustrating the sensitivity and specificity of peripheral natural killer cell levels at the best cutoff in diagnosing gastric cancer $(\mathrm{P}<0.001 ; 95 \% \mathrm{CI}=0.789-0.893)$. The dotted curves indicate the upper and lower end of the $95 \%$ CI. ROC, receiver operating characteristic; AUC, area under the curve.

\section{Discussion}

The present study aimed to investigate the diagnostic and prognostic value of peripheral lymphocyte subsets in GC. The levels of peripheral $\mathrm{CD}^{+}, \mathrm{CD}^{+}$and $\mathrm{CD}^{+} \mathrm{T}$ cells, CD19+ $\mathrm{B}$ cells and Tregs in patients with GC were not significantly different from those in HDs, but the proportion of peripheral NK cells in patients with GC (18.77\%) was significantly higher than that in HDs $(10.85 \%, \mathrm{P}<0.001)$ and cases of GU $(11.89 \%, \mathrm{P}<0.001)$. ROC curve analysis suggested that the peripheral NK cell levels may be used as a diagnostic marker for patients with GC. In addition to CEA, CA19-9 and CA72-4 serum markers are widely used for the early diagnosis of GC (25-27). Recent studies have indicated that non-coding RNAs, including Homo sapiens circular RNA 0000467, as well as epigenetic changes such as RAS association domain family member 10 (RASSF10) hypermethylation, Helicobacter pylori infection, $\mathrm{T}$ stage and other molecular markers (28), may also act as diagnostic markers for GC (29-32). In a previous study, the sensitivity and specificity of CA19-9 were determined to be 0.605 and 0.559 , respectively, while those for CEA were 0.686 and 0.593 , respectively, and those for CA72-4 were 0.667 and 0.592 , respectively (29). In the present study, an ROC curve was generated and the sensitivity and specificity of NK cells were determined to be 75.41 and $77.45 \%$, respectively, which were significantly higher than those for CEA, CA19-9 and
CA72-4. These results suggested that the peripheral NK cell levels may be used as a marker for the early diagnosis of GC.

The peripheral NK cell level is associated with various clinicopathological factors. It has been indicated that the level of peripheral NK cells is associated with lymph node metastasis in esophageal cancer (21). The present study determined that the level of peripheral NK cells in patients with GC was associated with the $\mathrm{T}$ stage, suggesting that it may be used to assess tumor progression in patients with GC. However, this requires further validation in future studies with larger sample sizes.

Numerous factors affect the prognosis of GC, with the most widely used factor being the TNM stage $(33,34)$. However, according to our clinical experience, it appears that patients with GC and the same TNM stage have different prognoses, and patients with the same TNM stage may have different molecular phenotypes. Molecular typing of GC also has an important role in the prognosis of patients (35). In recent years, an increasing number of studies have reported that certain factors, including high co-overexpression of epidermal growth factor receptor and receptor tyrosine kinase 3, low levels of microRNA-214 and high methylation of RASSF10, are associated with poor prognosis in patients with GC $(30,36,37)$. In the present study, the peripheral NK cell levels were determined to be an independent prognostic factor in patients with GC and patients who died within 5 years had a higher level of peripheral NK cells. Furthermore, the detection of NK cells only requires peripheral blood extraction, which is convenient to test and associated with low cost for patients. In the present study, the specificity and sensitivity of the NK cell ratio were slightly better than those for established prognostic markers for GC, including CEA and CA19-9. The present study determined that the NK cell ratio in the serum exhibited a positive correlation with that in matched GC tumor tissue samples. In the future, the NK cell ratio may be implemented in routine diagnostic/prognostic procedures for GC. However, the present study was limited by the sample size of patients with GC and HDs. In addition, only common peripheral blood lymphocytes were examined and the role of the proportion of NK cells in the prognosis and diagnosis of GC patients was demonstrated. However, there may be other lymphocyte clusters that warrant exploration.

In conclusion, the present study indicated that the peripheral NK cell levels may be used to identify patients with GC and are associated with certain clinicopathological 
Table I. Association between the characteristics of patients with gastric cancer and NK cell ratios in peripheral blood.

\begin{tabular}{|c|c|c|c|c|c|}
\hline \multirow[b]{2}{*}{ Clinicopathological feature } & \multicolumn{2}{|c|}{ NK cell level } & \multirow[b]{2}{*}{ Total (n) (\%) } & \multirow[b]{2}{*}{$\chi^{2}$-value } & \multirow[b]{2}{*}{ P-value } \\
\hline & Low $(\mathrm{n}=30)(\%)$ & High $(\mathrm{n}=92)(\%)$ & & & \\
\hline Sex & & & & 0.756 & 0.384 \\
\hline Male & $11(9.0)$ & $26(21.3)$ & $37(30.3)$ & & \\
\hline Female & $19(15.6)$ & $66(54.1)$ & $85(69.7)$ & & \\
\hline Age (years) & & & & 0.005 & 0.941 \\
\hline$\leq 60$ & $20(16.4)$ & $62(50.8)$ & $82(67.2)$ & & \\
\hline$>60$ & $10(8.2)$ & $30(24.6)$ & $40(32.8)$ & & \\
\hline Tumor diameter $(\mathrm{cm})$ & & & & 3.138 & 0.076 \\
\hline$\leq 4$ & $7(5.7)$ & $38(31.1)$ & $45(36.8)$ & & \\
\hline$>4$ & $23(18.9)$ & $54(44.3)$ & $77(63.2)$ & & \\
\hline Tumor location & & & & 1.508 & 0.470 \\
\hline Upper & $5(4.1)$ & $10(8.2)$ & $15(12.3)$ & & \\
\hline Middle & $9(7.3)$ & $38(31.1)$ & $47(38.5)$ & & \\
\hline Lower & $16(13.1)$ & $44(36.1)$ & $60(49.2)$ & & \\
\hline Tumor differentiation & & & & 0.394 & 0.530 \\
\hline High & $18(14.8)$ & $61(50.0)$ & $79(64.8)$ & & \\
\hline Low & $12(9.8)$ & $31(25.4)$ & $43(35.2)$ & & \\
\hline CA19-9 (U/ml) & & & & 0.689 & 0.406 \\
\hline$\leq 37$ & $25(20.5)$ & $70(57.4)$ & 95 (77.9) & & \\
\hline$>37$ & $5(4.1)$ & $22(18.0)$ & $27(22.1)$ & & \\
\hline CEA level (ng/ml) & & & & 1.710 & 0.191 \\
\hline$\leq 5$ & $21(17.2)$ & $52(42.6)$ & $73(59.8)$ & & \\
\hline$>5$ & $9(7.4)$ & $40(32.8)$ & $49(40.2)$ & & \\
\hline HP infection & & & & 0.265 & 0.607 \\
\hline- & 17 (13.9) & $57(46.7)$ & $74(60.6)$ & & \\
\hline+ & $13(10.7)$ & 35 (28.7) & $48(39.4)$ & & \\
\hline TNM stage & & & & 14.407 & 0.001 \\
\hline I & $18(14.8)$ & $21(17.2)$ & $39(32.0)$ & & \\
\hline II & $7(5.7)$ & $39(32.0)$ & $46(37.7)$ & & \\
\hline III & $5(4.1)$ & $32(26.2)$ & $37(30.3)$ & & \\
\hline T stage & & & & 16.505 & 0.001 \\
\hline 1 & $20(16.4)$ & $24(20.0)$ & $44(36.1)$ & & \\
\hline 2 & $5(4.1)$ & $26(21.3)$ & $31(25.4)$ & & \\
\hline 3 & $3(2.4)$ & $28(23.0)$ & $31(25.4)$ & & \\
\hline 4 & $2(1.6)$ & $14(11.5)$ & $16(13.1)$ & & \\
\hline $\mathrm{N}$ stage & & & & 9.749 & 0.021 \\
\hline 0 & $18(14.8)$ & $28(23.0)$ & $46(37.8)$ & & \\
\hline 1 & $6(4.9)$ & $22(18.0)$ & $28(22.9)$ & & \\
\hline 2 & $2(1.6)$ & $23(18.9)$ & $25(20.5)$ & & \\
\hline 3 & $4(3.2)$ & $19(15.6)$ & $23(18.8)$ & & \\
\hline
\end{tabular}

NK, natural killer; HP, Helicobacter pylori.

factors of malignancy. Of note, high levels of peripheral NK cells were associated with poor prognosis. The present study demonstrated that the peripheral NK cell levels may be a good diagnostic and prognostic marker for patients with GC.

\section{Acknowledgements}

The authors thank Dr Nicole Okoh (Liwen Bianji, Edanz Editing China; www.liwenbianji.cn/ac) for editing the English text of a draft of this manuscript. 
Table II. Univariate and multivariate analyses of prognostic factors for overall survival in patients with gastric cancer.

\begin{tabular}{|c|c|c|c|c|}
\hline \multirow[b]{2}{*}{ Variable } & \multicolumn{2}{|c|}{ Univariate analysis } & \multicolumn{2}{|c|}{ Multivariate analysis } \\
\hline & P-value & HR & $95 \% \mathrm{CI}$ & P-value \\
\hline Sex $[$ male $(n=85)$ vs. female $(n=37)]$ & 0.328 & 1.303 & $0.767-2.214$ & NS \\
\hline Age $[$ years; $\leq 60(n=82)$ vs. $>60(n=40)]$ & 0.574 & 0.864 & $0.519-1.438$ & NS \\
\hline $\begin{array}{l}\text { Tumor diameter } \\
{[\mathrm{cm} ; \leq 4(\mathrm{n}=45) \text { vs. }>4(\mathrm{n}=77)]}\end{array}$ & 0.155 & 0.702 & $0.431-1.144$ & NS \\
\hline Tumor location [upper/middle $(n=39)$ vs. lower $(n=73)$ ] & 0.597 & 1.136 & $0.708-1.823$ & NS \\
\hline Tumor differentiation [high $(n=79)$ vs. low $(n=43)]$ & 0.209 & 0.828 & $0.616-1.112$ & NS \\
\hline $\begin{array}{l}\text { CA19-9 level } \\
{[\mathrm{U} / \mathrm{ml} ; \leq 37(\mathrm{n}=95) \text { vs. }>37(\mathrm{n}=27)]}\end{array}$ & 0.362 & 1.316 & $0.729-2.375$ & NS \\
\hline $\begin{array}{l}\text { CEA level } \\
{[\mathrm{ng} / \mathrm{ml} ; \leq 5(\mathrm{n}=73) \text { vs. }>5(\mathrm{n}=49)]}\end{array}$ & 0.483 & 1.199 & $0.722-1.993$ & NS \\
\hline HP infection $[-(n=74)$ vs. $+(n=48)]$ & 0.096 & 1.505 & $0.930-2.435$ & NS \\
\hline T stage $[\mathrm{I}, \mathrm{II}(\mathrm{n}=75)$ vs. III, IV $(\mathrm{n}=47)]$ & 0.037 & 1.671 & $1.033-2.704$ & NS \\
\hline N stage $[0,1(n=74)$ vs. $2,3(n=48)]$ & 0.015 & 1.820 & $1.124-2.949$ & 0.064 \\
\hline NK cells [high $(n=92)$ vs. low $(n=30)]$ & 0.007 & 2.637 & $1.305-5.328$ & 0.018 \\
\hline
\end{tabular}

NK, natural killer; HP, Helicobacter pylori; NS, not significant.
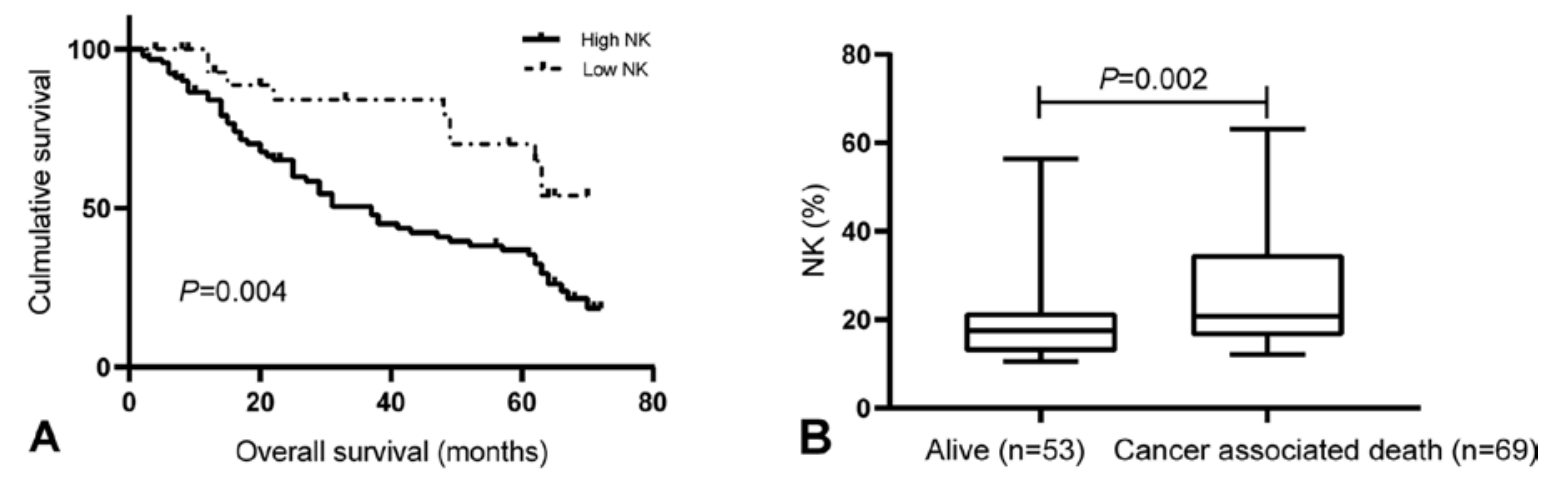

Figure 4. Association between peripheral NK cell levels and survival of patients with gastric cancer. (A) Kaplan-Meier plot depicting the association between peripheral NK cell levels (low or high) and overall survival ( $\mathrm{P}=0.004$; $95 \% \mathrm{CI}=1.27-3.71$ ). (B) Boxplot illustrating peripheral NK cell levels according to patients survival status after 5 years $(\mathrm{P}=0.019 ; 95 \% \mathrm{CI}=1.158-4.804)$. The NK levels of all patients in theses groups were tested before surgery. NK, natural killer.

\section{Funding}

This study was supported by the National Natural Science Foundation of China (grant no. 81672409), Jiangsu Provincial Medical Youth Talent (grant no. QNRC2016700), '333 Talent' Cultivating Project of Jiangsu Province (grant no. BRA2018394), Postgraduate Research \& Practice Innovation Program of Jiangsu Province (grant no. SJCX20_1153; SJCX20_1159; KYCX20_2674) and the Scientific and Technological Innovation and Demonstration Project of Nantong City (grant no. MS12018061).

\section{Availability of data and materials}

All data generated or analyzed during this study are included in this published article.

\section{Authors' contributions}

WJX and YLH conceived and designed the experiments. YYC and YF performed the experiments. QSM, JZL, XC and PM analyzed the data. YYC and YFL wrote the manuscript. WL and YFL searched the literature and performed statistical analysis. All authors read and approved the final manuscript.

\section{Ethics approval and consent to participate}

The present study was approved by the Ethics Committee of Nantong University (Nantong, China). Written informed consent was obtained from each participant.

\section{Patient consent for publication}

Not applicable. 


\section{Competing interests}

The authors declare that they have no competing interests.

\section{References}

1. DeSantis CE,Lin CC, Mariotto AB, Siegel RL, Stein KD, Kramer JL, Alteri R, Robbins AS and Jemal A: Cancer treatment and survivorship statistics, 2014. CA Cancer J Clin 64: 252-271, 2014.

2. Ferlay J, Soerjomataram I, Dikshit R, Eser S, Mathers C, Rebelo M, Parkin DM, Forman D and Bray F: Cancer incidence and mortality worldwide: Sources, methods and major patterns in GLOBOCAN 2012. Int J Cancer 136: E359-E386, 2015.

3. Wang B, Xu D, Yu X, Ding T, Rao H, Zhan Y, Zheng L and Li L: Association of intra-tumoral infiltrating macrophages and regulatory $\mathrm{T}$ cells is an independent prognostic factor in gastric cancer after radical resection. Ann Surg Oncol 18: 2585-2593, 2011.

4. Chow MT, Möller A and Smyth MJ: Inflammation and immune surveillance in cancer. Semin Cancer Biol 22: 23-32, 2012.

5. Zarin P, Wong GW, Mohtashami M, Wiest DL and Zúñiga-Pflücker JC: Enforcement of $\gamma \delta$-lineage commitment by the pre-T-cell receptor in precursors with weak $\gamma \delta$-TCR signals. Proc Natl Acad Sci USA 111: 5658-5663, 2014

6. Park K, He X, Lee HO, Hua X, Li Y, Wiest D and Kappes DJ: TCR-mediated ThPOK induction promotes development of mature (CD24-) gammadelta thymocytes. EMBO J 29 : $2329-2341,2010$

7. Bauer S, Groh V, Wu J, Steinle A, Phillips JH, Lanier LL and Spies T: Pillars article: Activation of NK cells and T cells by NKG2D, a receptor for stress-inducible MICA. Science. 1999 285: 727-729. J Immunol 200: 2231-2233, 2018.

8. Sardinha LR, Elias RM, Mosca T, Bastos KR, Marinho CR, D'Império Lima MR and Alvarez JM: Contribution of NK, NK $\mathrm{T}$, gamma delta $\mathrm{T}$, and alpha beta $\mathrm{T}$ cells to the gamma interferon response required for liver protection against trypanosoma cruzi. Infect Immun 74: 2031-2042, 2006.

9. Xu YF, Lu Y, Cheng H, Shi S, Xu J, Long J, Liu L, Liu C and Yu X: Abnormal distribution of peripheral lymphocyte subsets induced by PDAC modulates overall survival. Pancreatology 14: 295-301, 2014.

10. Yu A, Mansure JJ, Solanki S, Siemens DR, Koti M, Dias ABT, Burnier MM, Brimo F and Kassouf W: Presence of lymphocytic infiltrate cytotoxic T lymphocyte $\mathrm{CD} 3+, \mathrm{CD} 8+$, and immunoscore as prognostic marker in patients after radical cystectomy. PLoS One 13: e0205746, 2018.

11. Soo RA, Chen Z, Yan Teng RS, Tan HL, Iacopetta B, Tai BC and Soong R: Prognostic significance of immune cells in non-small cell lung cancer: meta-analysis. Oncotarget 9: 24801-24820, 2018.

12. Zinovkin DA, Pranjol MZI, Bilsky IA and Zmushko VA Tumor-associated T-lymphocytes and macrophages are decreased in endometrioid endometrial carcinoma with MELF-pattern stromal changes. Cancer Microenviron 11: 107-114, 2018.

13. Hagland HR, Lea D, Watson MM and Søreide K: Correlation of blood T-cells to intratumoural density and location of CD3+ and CD8+ T-cells in colorectal cancer. Anticancer Res 37: 675-683, 2017.

14. Wang K, Shen T, Siegal GP and Wei S: The CD4/CD8 ratio of tumor-infiltrating lymphocytes at the tumor-host interface has prognostic value in triple-negative breast cancer. Hum Pathol 69: 110-117, 2017.

15. Shah W, Yan X, Jing L, Zhou Y, Chen H and Wang Y: A reversed $\mathrm{CD} 4 / \mathrm{CD} 8$ ratio of tumor-infiltrating lymphocytes and a high percentage of CD4(+)FOXP3(+) regulatory $\mathrm{T}$ cells are significantly associated with clinical outcome in squamous cell carcinoma of the cervix. Cell Mol Immunol 8: 59-66, 2011.

16. Yasutomo K: The cellular and molecular mechanism of CD4/CD8 lineage commitment. J Med Invest 49: 1-6, 2002.

17. Hald SM, Bremnes RM, Al-Shibli K, Al-Saad S, Andersen S, Stenvold H, Busund LT and Donnem T: CD4/CD8 co-expression shows independent prognostic impact in resected non-small cell lung cancer patients treated with adjuvant radiotherapy. Lung Cancer 80: 209-215, 2013.

18. Xu T, Huang Z, Su B, Wang S, Wang D, Wang C, Wei W, Jiang J, Zhang $\mathrm{G}$, Yang $\mathrm{H}$ and $\mathrm{Hu} \mathrm{W}$ : Prognostic significance of circulating CD19+ B lymphocytes in EBV-associated nasopharyngeal carcinoma. Med Oncol 31: 198, 2014.

19. Nabeki B, Ishigami S, Uchikado Y, Sasaki K, Kita Y, Okumura H, Arigami T, Kijima Y, Kurahara H, Maemura K and Natsugoe S: Interleukin-32 expression and Treg infiltration in esophageal squamous cell carcinoma. Anticancer Res 35: 2941-2947, 2015.
20. Salama P, Phillips M, Grieu F, Morris M, Zeps N, Joseph D, Platell C and Iacopetta B: Tumor-infiltrating FOXP3+ T regulatory cells show strong prognostic significance in colorectal cancer. J Clin Oncol 27: 186-192, 2009.

21. Xu B, Chen L, Li J, Zheng X, Shi L, Wu C and Jiang J: Prognostic value of tumor infiltrating NK cells and macrophages in stage II+III esophageal cancer patients. Oncotarget 7: 74904-74916, 2016

22. Karakhanova S, Ryschich E, Mosl B, Harig S, Jäger D, Schmidt J, Hartwig W, Werner J and Bazhin AV: Prognostic and predictive value of immunological parameters for chemoradioimmunotherapy in patients with pancreatic adenocarcinoma. Br J Cancer 112: 1027-1036, 2015.

23. Maruyama T, Kono K, Mizukami Y, Kawaguchi Y, Mimura K, Watanabe M, Izawa S and Fujii H: Distribution of Th17 cells and FoxP3(+) regulatory $\mathrm{T}$ cells in tumor-infiltrating lymphocytes, tumor-draining lymph nodes and peripheral blood lymphocytes in patients with gastric cancer. Cancer Sci 101: 1947-1954, 2010.

24. Isobe Y,Nashimoto A, Akazawa K, Oda I, Hayashi K, Miyashiro I, Katai H, Tsujitani S, Kodera Y, Seto Y and Kaminishi M: Gastric cancer treatment in Japan: 2008 Annual report of the JGCA nationwide registry. Gastric Cancer 14: 301-316, 2011.

25. Ning S, Wei W, Li J, Hou B, Zhong J, Xie Y, Liu H, Mo X, Chen J and Zhang L: Clinical significance and diagnostic capacity of serum TK1, CEA, CA 19-9 and CA 72-4 levels in gastric and colorectal cancer patients. J Cancer 9: 494-501, 2018.

26. Feng F, Tian Y, Xu G, Liu Z, Liu S, Zheng G, Guo M, Lian X, Fan $\mathrm{D}$ and Zhang $\mathrm{H}$ : Diagnostic and prognostic value of CEA, CA19-9, AFP and CA125 for early gastric cancer. BMC Cancer 17: 737, 2017.

27. Shen M, Wang H, Wei K, Zhang J and You C: Five common tumor biomarkers and CEA for diagnosing early gastric cancer: A protocol for a network meta-analysis of diagnostic test accuracy. Medicine (Baltimore) 97: e0577, 2018.

28. Yoon JH, Park YG, Nam SW and Park WS: The diagnostic value of serum gastrokine $1(\mathrm{GKN} 1)$ protein in gastric cancer. Cancer Med 8: 5507-5514, 2019

29. Lu J, Zhang PY, Xie JW, Wang JB, Lin JX, Chen QY, Cao LL, Huang CM, Li P and Zheng CH: Hsa_circ_0000467 promotes cancer progression and serves as a diagnostic and prognostic biomarker for gastric cancer. J Clin Lab Anal 33: e22726, 2019.

30. Xue WJ, Feng Y, Wang F, Li P, Liu YF, Guo YB, Wang ZW and Mao QS: The value of serum RASSF10 hypermethylation as a diagnostic and prognostic tool for gastric cancer. Tumour Biol 37: 11249-11257, 2016.

31. Abbaszadegan MR, Taghehchian N, Aarabi A and Moghbeli M: MAEL Cancer-testis antigen as a diagnostic marker in primary stages of gastric cancer with Helicobacter pylori infection. J Gastrointest Cancer 51: 17-22, 2020.

32. Kouzu K, Tsujimoto H, Hiraki S, Nomura S, Yamamoto J and Ueno H: Diagnostic accuracy of T stage of gastric cancer from the view point of application of laparoscopic proximal gastrectomy. Mol Clin Oncol 8: 773-778, 2018.

33. Deng J, Liu J, Wang W, Sun Z, Wang Z, Zhou Z, Xu H and Liang H: Validation of clinical significance of examined lymph node count for accurate prognostic evaluation of gastric cancer for the eighth edition of the American joint committee on cancer (AJCC) TNM staging system. Chin J Cancer Res 30: 477-491, 2018.

34. Wei J, Yao T, Wang Y, Li L, Pan C and Zhang N: Prognostic analysis of stage III gastric cancer after curative surgery according to the newest TNM classification. Clin Transl Oncol 21: 232-238, 2019.

35. Xu TP, Wang WY, Ma P, Shuai Y, Zhao K, Wang YF, Li W, Xia R, Chen WM, Zhang EB and Shu YQ: Upregulation of the long noncoding RNA FOXD2-AS1 promotes carcinogenesis by epigenetically silencing EphB3 through EZH2 and LSD1, and predicts poor prognosis in gastric cancer. Oncogene 37: 5020-5036, 2018.

36. Moghbeli M, Makhdoumi Y, Soltani Delgosha M, Aarabi A, Dadkhah E, Memar B, Abdollahi A and Abbaszadegan MR: ErbB1 and ErbB3 co-over expression as a prognostic factor in gastric cancer. Biol Res 52: 2, 2019.

37. Ji B, Huang Y, Gu T, Zhang L, Li G and Zhang C: Potential diagnostic and prognostic value of plasma long noncoding RNA LINC00086 and miR-214 expression in gastric cancer. Cancer Biomark 24: 249-255, 2019.

This work is licensed under a Creative Commons Attribution-NonCommercial-NoDerivatives 4.0 International (CC BY-NC-ND 4.0) License. 